\title{
Urgensi Kejaksaan Diatur oleh Konstitusi
}

\author{
Urgency of Attorney Governed by the Constitution
}

\author{
Rommy Patra \\ Fakultas Hukum Universitas Tanjungpura \\ Jln. Ahmad Yani, Pontianak, Kalimantan Barat. \\ Tel./Fax: +62-561-740187E-mail: rommypatra@yahoo.co.id \\ Submitted: Oct 23, 2015; Reviewed: Nov 28, 2015; Accepted: Dec 4, 2015
}

\begin{abstract}
Attorney existence in the Indonesian constitutional structure has a dilemma for this position. On one side is the Prosecutor's law enforcement agencies to exercise power independently prosecution while on the other hand is part of a government institution under Law No. 16 of 2004 regarding the Attorney. The position of Attorney as an institution of government has been led to the independence of the Prosecutor is not optimal so that it appears stigma that the Prosecutor merely as a tool of the ruling power. In addition the terms of the arrangement just under the Act, the Attorney General has no legal standing as a constitutional organ that has the constitutional authority so that the current position does not reflect the urgency of its duties and functions. In an effort to organize the next Attorney institutions should be regulated directly by the Constitution. It is intended to make the Attorney as part of the main state organs have the same legal standing as other law enforcement agencies, the police and the courts (Supreme Court and Constitutional Court). As well as to strengthen and clarify the position as a state institution, prosecution authorities are focusing on the Attorney as central of authority, to fix the institutional relations between the members of law enforcement and related agencies and strengthen the independence of the Prosecutor in performing the function of prosecution in the constitutional structure of Indonesia.
\end{abstract}

Keywords: Attorney; Constitution; Independence

\begin{abstract}
Abstrak: Eksistensi kejaksaan dalam struktur ketatanegaraan Indonesia memiliki posisi yang dilematis selama ini. Di satu sisi, kejaksaan adalah lembaga penegak hukum yang menjalankan kekuasaan penuntutan secara independen, sedangkan di sisi lain adalah bagian dari lembaga pemerintahan berdasarkan Undang-Undang Nomor Nomor 16 Tahun 2004 tentang Kejaksaan Republik Indonesia. Kedudukan kejaksaan sebagai lembaga pemerintahan selama ini dirasakan menyebabkan independensi kejaksaan tidak optimal sehingga muncul stigma bahwa kejaksaan hanyalah sebagai alat kekuasaan dari yang memerintah. Selain itu, ditinjau dari segi pengaturan yang hanya berdasarkan undang-undang, kejaksaan tidak mempunyai legal standing sebagai organ konstitusi yang mempunyai kewenangan konstitusional sehingga kedudukannya saat ini tidak merefleksikan urgensitas tugas dan fungsi yang dimilikinya. Dalam upaya menata institusi kejaksaan ke depan sebaiknya diatur langsung oleh konstitusi. Hal ini dimaksudkan untuk menjadikan kejaksaan sebagai bagian dari main state organ
\end{abstract}


yang mempunyai legal standing sama seperti lembaga penegak hukum lainya, yaitu Kepolisian dan Pengadilan (Mahkamah Agung dan Mahkamah Konstitusi). Selain itu, untuk memerkuat dan memerjelas kedudukan sebagai lembaga negara, memusatkan kewenangan penuntutan berada di kejaksaan sebagai central of authority, membenahi hubungan kelembagaan antar sesama penegak hukum maupun lembaga terkait dan memperkuat independensi kejaksaan dalam menjalankan fungsi penuntutan dalam struktur ketatanegaraan Indonesia.

Kata Kunci: Kejaksaan; Konstitusi; Independensi

\section{PENDAHULUAN}

Kejaksaan sebagai institusi penegak hukum di Indonesia memiliki tugas dan fungsi yang sangat penting dalam melaksanakan kekuasaan negara di bidang penuntutan dan kewenangan lainnya yang diberikan oleh undang-undang. Secara kelembagaan, kejaksaan merupakan penghubung antara masyarakat dengan negara dalam menjaga tegaknya hukum dan norma yang berlaku di masyarakat. Oleh karena itu, dalam melaksanakan fungsinya, kejaksaan haruslah bekerja secara merdeka dan bebas dari intervensi manapun, termasuk dari pemerintah. ${ }^{1}$

Sayangnya, keberadaan institusi kejaksaan yang sangat penting ini belum dibarengi dengan pengaturan kelembagaan yang ideal dilihat dari segi dasar hukum pembentukan, kedudukan dan independensinya. Ditinjau dari dasar hukum pembentukannya, keberadaan kejaksaan sebagai lembaga negara tidak diatur langsung oleh UUD 1945 melainkan dengan UU No. 16 Tahun 2004 tentang Kejaksaan Republik Indonesia. Jika dibandingkan, eksistensi kejaksaan dengan kepolisian sebagai sesama penegak hukum di Indonesia, mengalami perbedaan yang cukup signifikan, khususnya terkait

Dio Ashar Wicaksana. (2013). "Kedudukan Kejaksaan RI dalam Sistem Hukum Tata Negara Indonesia”. Jurnal Fiat Justitia, 1(1): 3. landasan konstitusional keberadaan masingmasing lembaga. Timbul pertanyaan, mengapa keberadaan kejaksaan tidak diatur, sedangkan kepolisian diatur langsung oleh UUD 1945.

Kemudian, jika ditinjau dari segi kedudukan, berdasarkan konsideran UU No. 16 Tahun 2004, bahwa kejaksaan termasuk salah satu badan yang fungsinya berkaitan dengan kekuasaan kehakiman menurut UUD 1945. Sedangkan di dalam Pasal 2 ayat (1) menyebutkan, "Kejaksaan adalah lembaga pemerintahan yang melaksanakan kekuasaan negara di bidang penuntutan, serta kewenangan lain berdasarkan undang-undang." Persoalannya apakah kejaksaan merupakan bagian dari badan yudikatif karena memiliki keterkaitan dengan kekuasaan kehakiman atau memang murni sebagai lembaga yang merupakan bagian dari eksekutif karena disebut sebagai lembaga pemerintahan.

Karena persoalan kedudukan berkaitan erat dengan independensi kejaksaan dalam melaksanakan kekuasaan negara di bidang penuntutan, maka dalam melaksanakan tugas, fungsi dan wewenangnya, kejaksaan haruslah terlepas dari pengaruh kekuasaan pemerintah dan kekuasaan lainnya. Namun oleh UU No. 16 Tahun 2004 dinyatakan bahwa kejaksaan sebagai bagian dari lembaga pemerintahan dan Jaksa Agung diangkat ser- 
ta diberhentikan berdasarkan kewenangan Presiden sebagai kepala eksekutif.

Tentu saja, pengaturan ini tidak merefleksikan kejaksaan sebagai lembaga independen. Sebab, melihat karakteristik suatu lembaga negara independen biasanya pengangkatan jabatan maupun pemberhentian sebagai personil atau pimpinannya juga melibatkan persetujuan dari Dewan Perwakilan Rakyat (DPR), seperti dalam pengangkatan Panglima Tentara Nasional Indonesia (TNI), pengangkatan Kepala Kepolisian Republik Indonesia (Kapolri), pemilihan pimpinan Komisi Pemberantasan Korupsi (KPK) dan lain-lain.

Berdasarkan persoalan di atas, penulis dalam fokus tulisan ini mendasarkan kepada kajian terhadap eksistensi kejaksaan sebagai lembaga negara dalam struktur ketatanegaraan Indonesia. Hal ini tentu saja berkaitan dengan kedudukan, tugas, fungsi dan wewenang, independensi, serta hubungan kelembagaan antara kejaksaan dengan lembaga-lembaga negara lainnya.

\section{ANALISIS DAN PEMBAHASAN \\ Kedudukan Kejaksaan dalam Struktur Ketatanegaraan Indonesia}

Upaya untuk memahami dan menempatkan kedudukan kejaksaan dalam struktur ketatanegaraan jika ditinjau dari teori pemisahan kekuasaan (separation of powers) tidaklah mudah. Karena akan muncul persoalan terkait dengan apakah Kejaksaan itu sebagai sebuah lembaga eksekutif atau yudikatif. Menurut pendapat Beneč Štefan bahwa teori separation of powers dari Montesquieu tidak menjelaskan dimana cabang sistem penuntutan diletakkan. Walaupun di abad 14, posisi jaksa penuntut Kerajaan di Perancis merupakan pejabat publik yang mewakili raja, untuk melindungi hak kepemilikannya dan sebagai penuntut apabila adanya tindak kejahatan. $^{2}$

Munculnya persoalan mendudukan sistem penuntutan ke dalam suatu bagian kekuasaan negara di Perancis, dimulai pada saat "ministére public", yaitu semacam cikal bakalnya lembaga penuntut, menjadi sebuah jabatan yang tidak hanya memiliki fungsi yang bersifat publik, tapi juga memiliki fungsi pengawasan atas pengadilan. Selain itu, pada saat "Napoleon's Criminal Code" diterbitkan, "procereur d'etat" memperoleh kedudukannya sebagai penegak hukum, sehingga mulailah timbul permasalahan dan perlunya pemikiran kembali apakah lembaga kejaksaan bagian dari kekuasaan eksekutif atau yudikatif. ${ }^{3}$

Adanya permasalahan tersebut melahirkan dilema keberadaan sistem penuntutan dalam kekuasaan negara, karena apakah penuntutan sebagai badan publik memenuhi tugas eksekutif atau kekuasaan kehakiman? Kepada siapa hal tersebut dipertanggungjawabkan? Kepada pemerintah? Kepada pengadilan? Atau kepada parlemen? Jika bertitik tolak dari trias politica, maka jelas permasalahan tersebut tidak dapat terungkap karena Montesquieu tidak memberikan pemikiran di mana letak sistem penuntutan. Munculnya teori separation of powers pada saat itu, hanya untuk mencegah terjadinya

2 Beneč Štefan. (2003). "Independence of Prosecution". Makalah disampaikan dalam Seminar "The prosecutor's office in a democratic and constitutional state" organized by The General Prosecutor's Office and the Slovak National Supporting Committee of Europe 2000, April 2527, 2003, hlm. 14.

Ibid. 
kekuasaan raja yang mutlak. Oleh karena itu, persoalan meletakkan sistem penuntutan harus menjadi pemikiran yang serius dalam teori ilmu hukum dan konsep separation of powers Montesquieu menjadi hal yang perlu dipikirkan kembali dalam mengklasifikasikan lembaga-lembaga negara. ${ }^{4}$

Dalam konteks Indonesia, eksistensi kejaksaan sebagai lembaga penegak hukum sudah ada sejak lama. Jika ditarik jauh sampai ke era Majapahit, sudah adanya pelaksanaan tugas dan fungsi yang dilakukan mirip dengan tugas jaksa saat ini. Pada waktu itu dikenal dengan istilah Adhyaksa, salah satunya adalah peran yang dijalankan oleh Gadjah Mada selain melakukan penegakan hukum, juga sebagai pelaksana segala peraturan raja dan melaporkan perkara-perkara ke pengadilan. Tugas Gadjah Mada ini apabila dibandingkan dengan zaman sekarang sangatlah mirip dengan tugas jaksa, sehingga bisa disimpulkan bahwa kedudukan institusi Kejaksaan sejak zaman dahulu kala adalah sebagai alat negara dan pertanggungjawabannya kepada kepala negara yang saat itu adalah raja Hayam Wuruk. ${ }^{5}$

Pada perkembangan berikutnya, di era Hindia Belanda keberadaan jaksa dikenal dengan istilah officer van justitie, yang tugas pokoknya adalah menuntut seseorang ke pengadilan dalam suatu perkara tindak pidana. Pengaturan terhadap officer van justitie ini berdasarkan kepada Indische Staatsregeling yang substansinya mengacu kepada model pengaturan kejaksaan yang ada di Belanda. Istilah "kejaksaan dan jaksa" itu sendiri baru secara resmi digunakan di masa

\footnotetext{
$4 \quad$ Ibid.

Dio Ashar Wicaksana. (2013). Op.Cit, hlm. 4.
}

pendudukan Jepang untuk menggantikan istilah "officer van justitie" bagi petugas yang melakukan penuntutan perkara di pengadilan militer Jepang. Istilah ini secara resmi digunakan oleh undang-undang pemerintah pendudukan tentara Jepang No. 1/1942 yang kemudian diganti oleh Osamu Seirei No. 3/1942, No. 2/1944 dan No. 49/1944. ${ }^{6}$

Kemudian pada masa awal kemerdekaan dengan menggunakan Pasal II Aturan Peralihan UUD 1945 yang mengatakan bahwa, "segala badan negara dan peraturan yang ada masih langsung berlaku, selama belum diadakan yang baru menurut Undang-Undang Dasar ini”, maka pengaturan berkaitan dengan Kejaksaan juga masih mengacu kepada model pada era Hindia Belanda yang bersumber model pengaturannya kepada Kejaksaan yang ada di Belanda. Menurut Yusril Ihza Mahendra dalam tradisi di Belanda yang menganut sistem pemerintahan parlementer, semua hakim dan jaksa, adalah pegawai negeri. Secara struktur organisasi, personil dan keuangan baik jaksa maupun pengadilan berada di bawah Ministrie van Justititie (Kementerian Kehakiman). Namun secara fungsional dalam menjalankan tugas dan kewenangannya di bidang yudikatif, jaksa dan hakim adalah independen. Jadi, memang terdapat kerancuan kedudukan kejaksaan dalam sistem Belanda, yakni berada di antara dua sisi, antara eksekutif dan yudikatif. ${ }^{7}$

${ }^{6}$ Memaknai Independensi Kejaksaan di Indonesia (Kekuasaan Penuntutan), https://ilhamendra.wordpress.com $/ 2008 / 05 / 27 /$ kekuasaanpenuntutan/\#more-29, diakses pada tanggal 1 Juli 2015.

Yusril Ihza Mahendra. (2010), "Kedudukan Kejaksaan dan Posisi Jaksa Agung Dalam Sistem Presidensial Di Bawah UUD 1945", http://yusril. ihzamahendra.com/2010/08/20/kedudukan-kejaksaan-dan-posisi-jaksa-agung-dalam-sistem-pres- 
Dalam sistem hukum tata negara Belanda, Jaksa Agung diangkat oleh Perdana Menteri atas usul Menteri Kehakiman. Calon Jaksa Agung diambil dari pejabat karir berdasarkan kecakapan, pengalaman dan kemampuan. Jabatan Jaksa Agung bukanlah jabatan politik. Oleh karena tugas jaksa terkait langsung dengan pengadilan, maka dalam tradisi Belanda, Jaksa Agung disebut sebagai "Jaksa Agung (Hoofd Officer van Justitie) pada Mahkamah Agung (Hooge Raad)". Sedangkan perkembangan berikutnya, pada masa berlakunya UU Republik Indonesia Serikat (RIS) No. 1 Tahun 1950 tentang Susunan, Kekuasaan dan Jalan Pengadilan Mahkamah Agung Indonesia, pola penempatan Jaksa Agung di Mahkamah Agung seperti yang ada di Belanda tetap dilanjutkan. Pasal 2 UU tersebut mengatakan "Pada Mahkamah Agung adalah seorang Jaksa Agung dan dua orang Jaksa Agung Muda". Sedikit perubahan terjadi para proses rekruitmen Jaksa Agung dan Jaksa Agung Muda, yang dalam tradisi Belanda diangkat oleh Perdana Menteri atas usul Menteri Kehakiman, dalam Undang-Undang RIS diangkat oleh Presiden yang dalam praktiknya dilakukan atas usul Perdana Menteri. ${ }^{8}$

Kedudukan kejaksaan dengan model seperti di atas, terus digunakan Indonesia sampai era awal kemerdekaan hingga tahun 1959 di mana kedudukan kejaksaan adalah mendua. Secara organisasi, personil dan keuangan institusi ini berada di bawah Kementerian Kehakiman, namun secara fung-

idensial-di-bawah-uud-1945-oleh-prof-dr-yusrilihza-mahendra-pendahuluan-hampir-seluruh-negara-modern-di-du/\#, diakses pada tanggal 30 Juni 2015.

$8 \quad$ Ibid sional, lembaga ini bekerja dalam penyelenggaraan badan-badan peradilan, sehingga Jaksa Agung disebut sebagai Jaksa Agung pada Mahkamah Agung. Keberadaan kejaksaan yang rancu antara eksekutif dan yudikatif ini, baru berakhir pada tahun 1959, ketika UUD 1945 diberlakukan kembali melalui Dekrit Presiden 5 Juli 1959. Kemudian berdasarkan Keputusan Presiden No. 204 Tahun 1960, secara tegas memisahkan Kejaksaan dari Kementerian Kehakiman dan Mahkamah Agung, serta menjadikannya sebagai suatu institusi yang berdiri sendiri dan merupakan bagian langsung dari kabinet. Keputusan Presiden tersebut merupakan landasan hukum pertama yang menempatkan kejaksaan sepenuhnya sebagai bagian dari ranah kekuasaan eksekutif. Kemudian dibentuklah UU No. 15 Tahun 1961 tentang Ketentuanketentuan Pokok Kejaksaan Republik Indonesia yang menyatakan bahwa kejaksaan bukan saja "alat negara penegak hukum", tetapi dalam konteks penyelesaian revolusi, kejaksaan adalah "alat revolusi", yang tugas utamanya adalah sebagai "penuntut umum". 9

Pada perkembangan berikutnya, ketika kekuasaan Presiden Soekarno runtuh di tahun 1967, pemerintahan baru di bawah Presiden Soeharto tetap menggunakan UU No. 15 Tahun 1961 yang terus berlaku tanpa perubahan. Namun demikian, dalam praktiknya pada era Orde Baru, Kejaksaan Agung tidak lagi disebut sebagai Departemen Kejaksaan Agung dan Jaksa Agung tidak disebut pula sebagai Menteri Jaksa Agung. Institusi ini secara faktual disebut sebagai Kejaksaan Agung yang dipimpin oleh seorang Jaksa Agung. Namun kewenangan peng-

\footnotetext{
$9 \quad$ Ibid
} 
angkatan dan pemberhentian Jaksa Agung, sepenuhnya tetap berada di tangan Presiden. UU No. 15 Tahun 1961 tidak secara spesifik menyebutkan berapa lama Jaksa Agung akan memegang jabatannya. Akan tetapi setelah Pemilihan Umum 1971, Presiden Soeharto memulai sebuah konvensi ketatanegaraan, yakni Jaksa Agung selalu diangkat di awal kabinet dan berakhir masa jabatannya dengan berakhirnya masa bakti kabinet itu. Jaksa Agung yang disebut sebagai Menteri di dalam UU No 15 Tahun 1961 tidak lagi disebut demikian, namun sebagai bagian dari kabinet, Jaksa Agung diberi kedudukan setingkat Menteri Negara. ${ }^{10}$

Setelah berlaku selama 30 tahun akhirnya UU No. 15 Tahun 1961 diganti keberadaannya dengan UU No 5 Tahun 1991 tentang Kejaksaan Republik Indonesia. Berdasarkan konsideran dalam UU tersebut tidak lagi menyebut kejaksaan sebagai "alat negara" tetapi menyebutnya sebagai "lembaga pemerintahan yang melaksanakan kekuasaan negara di bidang penuntutan dalam tatanan susunan kekuasaan badan-badan penegak hukum dan keadilan”. Jaksa Agung sendiri "diangkat dan diberhentikan oleh serta bertanggung jawab kepada Presiden”. Penegasan bahwa pengangkatan dan pemberhentian Jaksa Agung adalah kewenangan Presiden, serta pertanggungjawabannya kepada Presiden, sekali lagi mempertegas bahwa kejaksaan sepenuhnya berada di bawah ranah kekuasaan eksekutif. Dalam UU No 5 Tahun 1991 juga tidak ada pembatasan apakah Jaksa Agung diangkat dari jaksa karier ataukah pengangkatan itu bersifat politik. Kedua-duanya dapat dilakukan oleh Pre- siden, berdasarkan pertimbangan subyektif Presiden sendiri. ${ }^{11}$

Perkembangan berikutnya pada era reformasi, keberadaan UU No. 5 Tahun 1991 diganti lagi dengan UU No. 6 tahun 2004 di mana secara substansi terkait dengan keberadaan Jaksa Agung tetaplah pejabat negara yang diangkat dan diberhentikan oleh Presiden. Dilihat dari sejarah lembaga kejaksaan di Indonesia dari awal terbentuk hingga sekarang memang merupakan suatu institusi yang berada di bawah ranah eksekutif dimana proses pengangkatan dan pemberhentian Jaksa Agung selalu berada di tangan Presiden, walaupun pernah melalui usul Menteri Kehakiman namun tetap saja secara pengangkatannya tetap ada di tangan Presiden. ${ }^{12}$

Melihat kedudukan Kejaksaan yang berada di ranah eksekutif menimbulkan banyak perdebatan, apakah Kejaksaan selaku institusi penegak hukum ditempatkan di dalam ranah eksekutif sudah sesuai dengan perspektif hukum tata negara atau tidak. Berdasarkan Pasal 24 ayat (3) UUD 1945 disebutkan bahwa, "Badan-badan lain yang fungsinya berkaitan dengan kekuasaan kehakiman diatur dengan undang-undang”. Mengacu kepada pasal tersebut, banyak pihak yang berpendapat bahwa kejaksaan merupakan salah satu badan yang fungsinya berkaitan dengan kekuasaan kehakiman, sehingga kejaksaan seharusnya berada di ranah yudikatif dan lepas dari pengaruh eksekutif. ${ }^{13}$

Ibid.

12 Dio Ashar Wicaksana. (2013). Kedudukan...Op.Cit, hlm. 6.

13 Menurut Jimly asshiddiqie yang dapat dikategorikan sebagai badan-badan lain yang fungsinya berkaitan dengan kekuasaan kehakiman adalah 
Berbeda dengan pandangan di atas, menurut Yusril Ihza Mahendra, seluruh ketentuan dalam BAB IX UUD 1945 sebenarnya membicarakan Kekuasaan Kehakiman dalam konteks Peradilan. Sementara lembaga pelaksana kekuasaan kehakiman disebutkan secara limitatif, yakni "dilakukan oleh sebuah Mahkamah Agung dan badan-badan peradilan yang berada di bawahnya...dan oleh sebuah Mahkamah Konstitusi” (Pasal 24 ayat (1) dan (2) UUD 1945).

Sementara Pasal 24 ayat (3) UUD 1945 menyatakan, "badan-badan lain yang fungsinya berkaitan dengan kekuasaan kehakiman diatur dalam undang-undang”. Ada yang menafsirkan bahwa kejaksaan merupakan salah satu badan yang fungsinya berkaitan dengan kekuasaan kehakiman, di

lembaga-lembaga atau badan-badan yang tugasnya berkaitan dengan peradilan dan penegakan hukum, yaitu berhubungan dengan fungsi-fungsi: (a) Penyelidikan, (b) penyidikan, (c) penuntutan, (d) pembelaan atau advokasi, (e) penyelesaian sengketa dan mediasi atau pendamaian, (f) peradilan, penghakiman dan penghukuman, (g) pemasyarakatan, (h) pelaksanaan putusan pengadilan selain pemasyarakatan, dan (i) pemulihan nama baik atau rehabilitasi, (j) pemberian grasi, (k) pemberian amnesti, (l) pemberian abolisi, (m) persaksian, dan (n) pemberian keterangan berdasarkan keahlian. Dari semua fungsi tersebut, yang terpenting adalah fungsi penyelidikan, penyidikan, dan penuntutan. Badan-badan yang dapat melakukan fungsi penyelidikan pelanggaran hukum ataupun hak asasi manusia adalah (a) Kepolisian Negara, (b) Tentara Nasional Indonesia (TNI) Angkatan Laut, (c) para Pejabat Penyidik Pegawai Negeri Sipil (PPNS), (d) Komisi Nasional Hak Asasi Manusia (Komnasham), (e) Komisi Pemberantasan Tindak Pidana Korupsi (KPK), (f) Badan Pemeriksa Keuangan dan Pembangunan (BPKP), dan (g) Badan Pemeriksa Keuangan (BPK). Badan-badan yang dapat menjalankan fungsi penyidikan pro-justisia adalah (a) Kejaksaan, (b) Komisi Pemberantasan Tindak Pidana Korupsi, dan (c) Pejabat Penyidik Pegawai Negeri Sipil (PPNS). Sedangkan badan-badan yang melakukan penuntutan adalah (a) Kejaksaan, dan (b) Komisi Pemberantasan Tindak Pidana Korupsi. Lihat Jimly Asshiddiqie, Lembaga-lembaga Negara, Organ Konstitusional Menurut UUD 1945, hlm. 3 http://www.jimly.com/makalah/namafile/50/ORGAN-ORGAN_KONSTITUSI.doc, diakses pada tanggal 2 Juli 2015 mana menurut Yusril kalau hanya "berkaitan" tidaklah harus diartikan kejaksaan itu sebagai bagian dari kekuasaan kehakiman. Karena bisa juga dikatakan bahwa institusi Rumah Tahanan dan Lembaga Pemasyarakatan juga terkait dengan kekuasaan kehakiman, dalam konteks teori criminal justice system. Namun dalam sejarahnya, Rumah Tahanan dan Lembaga Pemasyarakatan tetap berada di bawah Kementerian Hukum dan HAM yang merupakan ranah kekuasaan eksekutif. $^{14}$

Selain itu, apabila melihat ketentuan dari Pasal 24 ayat (3) UUD 1945 tidak menyebutkan bahwa "badan-badan lain" tersebut haruslah dimasukkan ke dalam ranah yudikatif melainkan hanya menyebutkan bahwa ketentuan "badan-badan lain" tersebut diatur di dalam undang-undang. Sedangkan di dalam UU Kejaksaan ditegaskan bahwa Kejaksaan adalah lembaga pemerintahan yang melaksanakan kekuasaan negara di bidang penuntutan- serta kewenangan lain berdasarkan undang-undang. Hal yang bisa ditegaskan dari pasal tersebut adalah kejaksaan merupakan lembaga pemerintahan, sehingga kedudukan kejaksaan dalam sistem ketatanegaraan Indonesia merupakan bagian dari pemerintahan. Pendapat demikian juga diperkuat oleh pernyataan Bagir Manan yang menyebutkan bahwa kejaksaan adalah badan pemerintahan. Dengan demikian, pimpinannya juga adalah pimpinan dari

\footnotetext{
14 Yusril Ihza Mahendra. (2010). Kedudukan Kejaksaan dan Posisi Jaksa Agung Dalam Sistem Presidensial Di Bawah UUD 1945, http://yusril. ihzamahendra.com $/ 2010 / 08 / 20 /$ kedudukankejaksaan-dan-posisi-jaksa-agung-dalam-sistempresidensial-di-bawah-uud-1945-oleh-prof-dryusril-ihza-mahendra-pendahuluan-hampir-seluruh-negara-modern-di-du/\#, diakses pada tanggal 30 Juni 2015.
} 
suatu badan pemerintahan dan ditafsirkan bahwa yang dimaksud badan pemerintahan adalah kekuasaan eksekutif."15

\section{Independensi Kejaksaan}

Berbicara tentang independensi kejaksaan pasti tidak dapat dilepaskan dari pertanyaan tentang bagaimana kejaksaan dapat bekerja secara independen dalam fungsinya sebagai penegak hukum, karena kedudukannya seba-gai bagian dari lembaga pemerintahan. Ini menimbulkan suatu kontradiksi di mana satu sisi kejaksaan adalah bagian ranah eksekutif yang tidak lain berada di bawah Presiden selaku pemegang kekuasaan eksekutif, namun di sisi lain Kejaksaan harus melakukan fungsi, tugas dan wewenangnya sebagai institusi penegak hukum. ${ }^{16}$

Terkait independensi ini, sebenarnya mesti dibagi menjadi dua aspek, yakni: independensi secara institusional (kelembagaan) dan independensi secara fungsional. Independensi secara lembaga berarti bahwa kejaksaan ditempatkan dalam posisi yang independen secara kelembagaan. Kejaksaan memang semestinya lebih baik ditempatkan mandiri secara kelembagaan dan lepas dari kekuasaan manapun. Namun yang terpenting dari persoalan independensi bukanlah independensi kelembagaan, melainkan independensi fungsional. Independensi fungsional adalah bahwa Jaksa itu bisa bebas dan merdeka dalam menjalankan tugasnya untuk menuntut ataukah tidak menuntut. ${ }^{17}$

\footnotetext{
15 Dio Ashar Wicaksana. (2013). Kedudukan...Op.Cit, hlm. 7.

16 Ibid.

17 Ahmad Andriadi. (2012), Kedudukan Kejaksaan Dalam Sistem Ketatanegaraan Republik Indonesia (Telaah Kritis Terhadap Undang-Undang Nomor 16 Tahun 2004 tentang Kejaksaan Republik Indonesia). Skripsi. Bagian Hukum Tata Negara Fakultas Hukum Universitas Hasanudin Makassar,
}

Persoalan seputar kedudukan dan independensi kejaksaan dalam struktur ketatanegaraan suatu negara tidak hanya terjadi di Indonesia saja. Di negara semaju Amerika Serikat pun, persoalan semacam ini juga terjadi. Situasi Jaksa Agung sebagai pim-pinan institusi kejaksaan di Amerika Serikat digambarkan oleh Robert Palmer sebagai kondisi yang "schizophrenic”, karena memerankan dua fungsi sekaligus, yaitu sebagai "petugas hukum" (law officer) dan juga sebagai "petugas eksekutif” (executive officer). ${ }^{18}$ Kondisi seperti ini tentu saja dapat mempengaruhi independensi kejaksaan dalam penegakan hukum.

Perwujudan lembaga kejaksaan yang independen sebenarnya sangat dipengaruhi oleh independensi pimpinan lembaga penuntutan tersebut. Pimpinan lembaga penuntutan yang sering disebut sebagai general prosecutor/attorney general (yang dalam bahasa Indonesianya Jaksa Agung) sebagai puncak pimpinan lembaga penuntutan memiliki tanggung jawab yang besar. Independensi Jaksa Agung ini sangat dipengaruhi oleh pola pemilihan, pemberhentian dan pertanggung jawaban. Ditinjau dari aspek pemilihan, terdapat lima tipe pemilihan Jaksa Agung, yakni: (1) dipilih secara langsung oleh masyarakat (direct election by citizen voters), (2) dipilih oleh anggota legislatif (election by the legislature), (3) dipilih oleh anggota eksekutif (appointment by members of executive), (4) dipilih oleh anggota yudikatif (appointment by members of the

\footnotetext{
hlm. 44-45.

18 Memaknai Independensi Kejaksaan di Indonesia (Kekuasaan Penuntutan), https://ilhamendra.wordpress.com $/ 2008 / 05 / 27 /$ kekuasaanpenuntutan/\#more-29, diakses pada tanggal 1 Juli 2015 .
} 
judiciary), dan (5) dipilih oleh anggota kejaksaan (appointment by members of the procuracy). Dari lima tipe pemilihan tersebut, tipe pemilihan Jaksa Agung yang dipilih oleh parlemen dianggap lebih dapat memberikan jaminan independensi. Selain memberikan jaminan independensi pola pemilihan ini pun berakibat adanya masa jabatan Jaksa Agung yang lebih pasti “fix term", biasanya 5 (tahun). ${ }^{19}$

Dalam konteks Indonesia, berdasarkan UU No. 16 Tahun 2004 tentang Kejaksaan RI, pengaturan berkaitan dengan independensi institusi kejaksaan masih memiliki sejumlah persoalan, yaitu: ${ }^{20}$ Pertama, berdasarkan Pasal 19 UU No. 16 Tahun 2004 dinyatakan bahwa Jaksa Agung adalah pejabat negara yang diangkat dan diberhentikan oleh Presiden. Dengan kedudukannya yang diangkat dan diberhentikan oleh Presiden, maka Jaksa Agung menjadi tidak independen. Karena posisi Jaksa Agung adalah setingkat dengan menteri yang berarti merupakan bagian dari kabinet dan menjadi pembantu serta bertanggung jawab penuh kepada Presiden. Dikhawatirkan dengan kedudukan sebagai bawahan langsung atau pembantu Presiden, maka sewaktu-waktu dengan kekuasaan yang dimilikinya Presiden bisa saja mengintervensi dan mengendalikan Jaksa Agung dengan jajaran yang dimilikinya untuk menggunakan kekuasaan penuntutan pidana menghantam lawan-lawan politiknya. Seperti pada era Orde Baru dimana instrumen dan aparat hukum termasuk kejaksaan digunakan oleh Presiden Soeharto untuk menghukum serta membungkam

\footnotetext{
19 Ibid

20 Ahmad Andriadi, (2012), Kedudukan....Op.Cit, hlm. 48-50.
}

orang atau kelompok yang kritis terhadapnya dengan tuduhan subversif. Selain itu intervensi juga dapat dilakukan oleh Presiden untuk memerintahkan kepada Jaksa Agung untuk tidak menyidik dan menuntut orang atau kelompok tertentu karena terkait dengan kepentingan politiknya.

Kedua, mengenai pemberhentian Jaksa Agung. Dalam Pasal 22 ayat (1) dinyatakan bahwa Jaksa Agung diberhentikan dengan hormat dari jabatannya karena: a) meninggal dunia; b) permintaan sendiri; c) sakit jasmani atau rohani terus-menerus; d) berakhir masa jabatannya; e) tidak lagi memenuhi salah satu syarat sebagaimana dimaksud dalam Pasal 21. Pada Pasal 22 ayat (1) huruf d dinyatakan bahwa Jaksa Agung berhenti apabila berakhir masa jabatannya. Namun dalam pasal tersebut, tidak ada penjelasan yang rinci tentang berapa lama periode masa jabatan Jaksa Agung. Keadaan ini berpotensi menghilangkan independensi kekuasaan penuntutan karena Jaksa Agung dapat diberhentikan kapan pun tergantung pada keinginan Presiden. ${ }^{21}$

Oleh karena itu, berdasarkan Pasal 19 ayat (2) jo. Pasal 22 UU No. 16 Tahun 2004 dapat disimpulkan bahwa kedudukan Jaksa Agung tidak independen karena sangat bergantung kepada kewenangan Presiden untuk diangkat dan diberhentikan. Posisi Jaksa Agung seperti itu dapat menimbulkan dua masalah yang dengan istilah "dual obliga-

\footnotetext{
21 Keberadaan Pasal 22 ayat (1) huruf d ini oleh MK dinyatakan konstitusional bersyarat (conditionally constitutional) sebelum dilakukannya legislative review yang berlaku prospektif ke depan. Artinya, masa jabatan Jaksa Agung dinyatakan konstitusional dengan tafsir berakhirnya masa jabatan Jaksa Agung berakhir bersamaan dengan masa jabatan Presiden yang mengangkatnya sesuai praktek ketatanegaraan di Indonesia. Lihat Putusan MK Nomor 49/PUU-VIII/2010.
} 
tion" dan "conflicting loyalties". ${ }^{22}$ Karena di satu sisi sebagai penegak hukum yang harus bekerja mandiri dan obyektif, sedangkan di sisi lain merupakan lembaga pemerintahan yang tunduk kepada instruksi Presiden yang bisa saja mengintervensi tugas dan fungsi kejaksaan sebagai lembaga penegak hukum

Kedudukan kejaksaan yang kontradiktif tersebut, tentu akan memengaruhi independensinya, sehingga diperlukan bentuk pengaturan yang tepat untuk menjaga independensinya itu melalui dua opsi: Pertama, jika kejaksaan merupakan bagian dari kekuasaan eksekutif, maka diperlukan suatu aturan hukum yang memberikan jaminan independensi dan membatasi intervensi kekuasaan lain; Kedua, membentuk kejaksaan yang mandiri secara penuh yang tidak berada di bawah kekuasaan eksekutif tetapi membentuk mekanisme pertanggungjawaban kepada parlemen. Olehnya itu, diperlukan adanya aturan hukum yang mengatur secara jelas keberadaan sistem penuntutan dan lembaga penuntutan dalam kekuasaan negara. Menurut Milan Hanzel, penentuan posisi lembaga penuntutan dalam aturan hukum sangatlah penting, pengaturan hukum posisi lembaga ini tidak hanya cukup diatur dalam aturan hukum biasa (undang-undang) tetapi haruslah diatur dalam materi konstitusi. ${ }^{23}$ Hal ini berarti, lembaga pelaksana kekuasaan penuntutan, yaitu Kejaksaan sebaiknya merupakan lembaga konstitusional (constitutional body).

22 Ahmad Andriadi, (2012), Kedudukan...Op.Cit, hlm. 51 .

23 Memaknai Independensi Kejaksaan di Indonesia (Kekuasaan Penuntutan), https://ilhamendra.wordpress.com $/ 2008 / 05 / 27 /$ kekuasaanpenuntutan/\#more-29, diakses pada tanggal 1 Juli 2015.

\section{Urgensi Kejaksaan Menjadi Organ Kon-} stitusi

Materi muatan atau substansi konstitusi pada intinya menyangkut prinsip pengaturan dan pembatasan kekuasaan negara guna mewujudkan tujuan nasional. Karena itu, menurut William G. Andrews, "under constitutionalism, two types of limitations impinge on government. Power proscribe and procedures prescribed". Konstitusionalisme mengatur dua hubungan yang saling berkaitan satu sama lain, yaitu: pertama, hubungan antara pemerintahan dengan warga negara; dan kedua, hubungan antara lembaga pemerintahan yang satu dengan lembaga pemerintahan yang lain. Isi konstitusi dimaksudkan untuk mengatur mengenai tiga hal penting: (a) menentukan pembatasan kekuasaan organ-organ negara, (b) mengatur hubungan antara lembaga-lembaga negara yang satu dengan yang lain, dan (c) mengatur hubungan kekuasaan antara lembaga-lembaga negara dengan warga negara. ${ }^{24}$

Meski salah satu substansi dari konstitusi adalah mengatur tentang lembaga negara, namun sayangnya, pada amendemen UUD 1945 berkaitan dengan pengaturan lembaga negara tidak terdapat ketentuan yang jelas mengenai apa yang menjadi definisi dari istilah lembaga negara dan apa yang menjadi ukuran bahwa suatu lembaga negara keberadaannya dapat dikategorikan sebagai lembaga yang diatur langsung dengan konstitusi. Tidak adanya pengaturan ini tentu menimbulkan banyak penafsiran

\footnotetext{
24 Jimly Asshiddiqie. (2008). "Hubungan Antar Lembaga Negara Pasca Perubahan UUD 1945", Bahan ceramah pada Pendidikan dan Latihan Kepemimpinan (Diklatpim) Tingkat I Angkatan XVII Lembaga Administrasi Negara. Jakarta, 30 Oktober 2008, hlm. 1-2.
} 
dalam mendefinisikan dan mengklasifikasikan apa itu lembaga negara.

Konsepsi tentang lembaga negara secara terminologis bukanlah istilah yang tunggal dan seragam. Di dalam kepustakaan Inggris, untuk menyebut lembaga negara digunakan istilah political institution, sedangkan dalam terminologi Bahasa Belanda terdapat istilah staatorgan. Sementara itu, dalam Bahasa Indonesia menggunakan istilah lembaga negara, badan negara, atau organ negara ${ }^{25}$. Dalam Kamus Hukum Foc-kema Andreae yang diterjemahkan oleh Saleh Adiwinata dkk, disebutkan, kata orgaan juga diartikan sebagai perlengkapan. Karena itu istilah lembaga negara, organ negara, dan alat perlengkapan negara seringkali dipertukarkan satu sama lain. ${ }^{26}$

Adapun tujuan diadakannya lembagalembaga negara atau alat-alat perlengkapan negara adalah untuk menjalankan fungsi negara dan menjalankan fungsi pemerintahan secara aktual. Dengan kata lain, lembaga-lembaga negara tersebut harus dapat membentuk satu kesatuan proses yang satu sama lain saling berhubungan dalam rangka penyelenggaraan fungsi negara. ${ }^{27}$

Dengan demikian, salah satu materi penting dan selalu ada dalam konstitusi adalah pengaturan tentang lembaga negara. Hal ini dapat dimengerti karena kekuasaan negara pada akhirnya diterjemahkan ke dalam tugas dan wewenang lembaga negara.

25 Ni'matul Huda, (2007), Lembaga Negara Dalam Masa Transisi Demokrasi, Yogyakarta, UII Press, hlm, 76.

26 Ibid, hlm. 31.

27 Firmansyah Arifin dkk, (2005), Lembaga Negara dan Sengketa Kewenangan Antarlembaga Negara, Jakarta, Konsorsium Reformasi Hukum Nasional bekerjasama dengan Mahkamah Konstitusi, hlm. 31 .
Sebab menurut Hans Kelsen, pada dasarnya negara itu bertindak hanya melalui organorgan atau lembaganya. Tercapai tidaknya tujuan bernegara berujung pada bagaimana lembaga-lembaga negara tersebut melaksanakan tugas dan wewenang konstitusionalnya, serta hubungannya antarlembaga negara. Pengaturan lembaga negara dan hubungan antarlembaga negara merefleksikan pilihan dasar-dasar kenegaraan yang dianut oleh suatu negara. ${ }^{28}$

Keberadaan lembaga negara merupakan salah satu subtansi yang penting dalam konstitusi. Karena konstitusi merupakan basis atau dasar yang terkuat bagi eksistensi suatu lembaga negara ketika keberadaannya diatur langsung oleh konstitusi sebagai norma hukum dasar tertinggi. Lembagalembaga negara yang dibentuk dan diberi kewenangan langsung oleh konstitusi tentu memiliki prestise dan kedudukan yang lebih kuat sebagai lembaga dengan kewenangan konstitusional yang dianggap mempunyai urgensi dibandingkan dengan lembaga-lembaga lain yang keberadaannya hanya diatur berdasarkan peraturan perundang-undangan di bawah konstitusi.

Salah satu persoalan yang mengemuka adalah terkait dengan tidak diaturnya lembaga kejaksaan sebagai organ konstitusi. Ditinjau dari segi historis berdasarkan UUD 1945 yang disahkan pada tanggal 18 Agustus 1945, memang tidak ditemukan satu katapun yang menyebut institusi kejaksaan, baik dalam batang tubuh maupun penjelasannya. Demikian pula setelah UUD 1945 mengalami empat kali perubahan di era reformasi,

\footnotetext{
28 Hans Kelsen, (2006), Teori Umum tentang Hukum dan Negara, Bandung, Nusamedia, hlm. 279.
} 
keberadaan institusi kejaksaan tetap bukanlah bagian dari lembaga negara yang diatur langsung oleh konstitusi. Hal ini menimbulkan pertanyaan, mengapa kejaksaan keberadaannya tidak diatur oleh UUD 1945, padahal jika dibandingkan dengan institusi penegak hukum lain, yaitu kepolisian yang keberadaannya sebagai organ konstitusi diatur langsung oleh UUD 1945 pada Pasal 30 ayat (4), yaitu: "Kepolisian Negara Republik Indonesia sebagai alat negara yang menjaga keamanan dan ketertiban masyarakat bertugas melindungi, mengayomi, melayani masyarakat, serta menegakkan hukum".

Apakah sebagai sama-sama penegak hukum, institusi kepolisian memiliki urgensi yang lebih penting daripada kejaksaan, sehingga eksistensi institusi kepolisian diatur langsung oleh UUD 1945 sebagai organ konstitusi sedangkan Kejaksaan tidak. Menurut Jimly Asshiddiqie dalam rancangan perubahan UUD, semula tercantum pengaturan mengenai Kejaksaan Agung. Akan tetapi, karena tidak mendapatkan kesepakatan, maka sebagai gantinya disepakatilah rumusan Pasal 24 ayat (3) UUD 1945, yaitu: "Badan-badan lain yang fungsinya berkaitan dengan kekuasaan kehakiman diatur dalam undang-undang". ${ }^{29}$

Namun, karena yang disebut dalam Pasal 24 ayat (3) tersebut di atas adalah badan-badan, berarti jumlahnya lebih dari satu. Artinya, selain Kejaksaan Agung, masih ada lagi lembaga lain yang fungsinya juga berkaitan dengan kekuasaan kehakiman, yaitu yang menjalankan fungsi penyelidikan, penyidikan, dan/atau penuntutan. Lembaga-

\footnotetext{
29 Jimly Asshiddiqie, (2008), Hubungan....Op.Cit,
} hlm. 14. lembaga dimaksud misalnya adalah Komisi Nasional Hak Asasi Manusia (Komnas HAM), Komisi Pemberantasan Tindak Pidana Korupsi (KPK) dan sebagainya. Lembaga-lembaga ini, seperti halnya kejaksaan, meskipun tidak secara eksplisit disebut dalam UUD 1945, tetapi sama-sama memiliki constitutional importance dalam sistem konstitusional berdasarkan UUD 1945. ${ }^{30}$

Masih menurut Jimly Asshiddiqie, meskipun pengaturan dan pembentukan institusi Kejaksaan, KPK, Komnas HAM hanya didasarkan atas undang-undang, tidak ditentukan sendiri dalam UUD, tetapi keberadaannya sebagai lembaga negara mempunyai apa yang disebut sebagai constitutional importance yang sama dengan lembaga-lembaga negara lainnya yang disebutkan secara eksplisit dalam UUD 1945. Sama halnya dengan keberadaan kejaksaan dan kepolisian dalam setiap sistem negara demokrasi konstitusional ataupun negara hukum yang demokratis, keduanya mempunyai derajat kepentingan (importance) yang sama. Meski dalam UUD 1945, yang ditentukan kewenangannya hanya kepolisian, sedangkan kejaksaan tidak disebut, namun hal tersebut tidak dapat dijadikan alasan untuk menilai bahwa kepolisian lebih penting daripada kejaksaan. Oleh karena kedua lembaga itu sama-sama penting atau memiliki constitutional importance yang sama, sebab setiap negara yang menganut prinsip demokrasi konstitusional atau negara hukum yang demokratis, haruslah memiliki perangkat kelembagaan berupa kepolisian dan kejaksaan sebagai lembaga-lembaga penegak hukum yang efektif. ${ }^{31}$

30 Ibid, hlm. 15.

31 Ibid. 
Interpretasi yang dilakukan oleh Jimly seperti di atas yang menyatakan kejaksaan mempunyai constitutional importance meski hanya sebagai lembaga yang dibentuk dengan undang-undang, tetap tidak dapat menutupi fakta bahwa eksistensi kejaksaan bukan sebagai bagian dari organ konstitusi. Padahal menurut Milan Hanzel, penentuan posisi lembaga penuntutan, yaitu kejaksaan dalam aturan hukum sangatlah penting, dimana pengaturan hukum posisi lembaga ini tidak hanya cukup diatur dalam aturan hukum biasa (undang-undang), tetapi haruslah diatur dalam konstitusi. Hal ini berarti lembaga pelaksana kekuasaan penuntutan, yaitu kejaksaan adalah harus merupakan lembaga konstitusional (constitutional body). Sebenarnya pengaturan institusi kejaksaan dalam konstitusi suatu negara bukanlah merupakan hal yang baru, karena ternyata di dunia ini terdapat hampir 90 (sembilan puluh) negara yang mengatur lembaga Kejaksaan dan/atau Jaksa Agungnya dalam Undang-Undang Dasar. $^{32}$

Maka dari itu, penguatan eksistensi kejaksaan untuk diatur ke dalam konstitusi memiliki sejumlah urgensi, yaitu: Pertama, untuk memperkuat eksistensi kejaksaan menjadi lembaga negara utama (main state organ) yang keberadaannya diatur langsung oleh UUD 1945 sesuai dengan tugas dan fungsinya yang sangat urgen dalam kehidupan bernegara sebagai lembaga penegak hukum. Pengaturan eksistensi kejaksaan kedalam konstitusi akan memperjelas kedudukannya sebagai organ konstitusi dalam struktur ketatanegaran Indonesia. Kejaksaan

32 Ahmad Andriadi, (2012), Kedudukan...Op.Cit, hlm. 46. sebagai organ konstitusi akan memiliki kewenangan konstitusional, yaitu kewenangan yang diberikan langsung oleh konstitusi, sehingga kejaksaan memiliki legal standing yang jika dalam pelaksanaan kewenangannya terjadi konflik kewenangan dengan organ konstitusi lain, maka penyelesaian sengketanya dapat diajukan kepada MK sebagai lembaga yang berwenang untuk memutus sengketa kewenangan konstitusional antar lembaga negara.

Kedua, penguatan eksistensi kejaksaan ke dalam konstitusi sekaligus dijadikan momen penataan hubungan kelembagaan dengan institusi lain yang terkait dengan kekuasaan kehakiman. Seperti hubungan antara Kejaksaan dengan Komnas HAM dalam penyelesaian pelanggaran berat HAM yang selama ini tampak bahwa rekomendasi hasil penyelidikan dari Komnas HAM mengalami stagnasi dan mandek di kejaksaan tanpa adanya tanda-tanda akan dilanjutkan ke tahapan penyidikan. ${ }^{33}$ Selain itu, potensi sengketa kewenangan antarlembaga negara mungkin saja terjadi dengan adanya dualisme kewenangan penyidikan maupun penuntutan, seperti dalam penanganan perkara tindak pidana korupsi antara Kejaksaan, Kepolisian

33 Hal ini ditengarai bahwa Kejaksaan mengalami intervensi politik untuk tidak melakukan penyidikan dalam menindaklanjuti rekomendasi komnasham. Tuduhan yang muncul seperti ini cukup beralasan dikarenakan Kejaksaan seperti selalu mencari dalih jika dipertanyakan bagaimana kelanjutan penanganan terhadap kasus pelanggaran HAM. Menurut Komnasham setidaknya ada sejumlah kasus pelanggaran HAM yang terhenti di Kejaksaan Agung, yaitu peristiwa Trisakti, Semanggi I dan II, peristiwa kerusuhan Mei 1998, peristiwa penculikan aktivis, peristiwa Talangsari Lampung, dan peristiwa Wasior dan Wamena. Lihat Ifdhal Kasim, 2011, Komnas HAM dan Tantangannya Dewasa Ini, Jurnal Dignitas: HAM dan Realitas Transisional, Volume VII, No. 1 Tahun 2011, Jakarta, Elsam, hlm. 83. 
dan KPK.

Ke depannya, untuk dapat menyelesaikan persoalan konflik kewenangan sebaik nya melalui mekanisme sengketa kewenangan yang ada di MK, bukan diselesaikan secara politis. Tentu di sini dalam konteks amandemen UUD 1945 tidak hanya kejaksaan yang diperkuat dengan diatur oleh konstitusi melainkan juga sejumlah lembaga lain yang memiliki urgensi yang sama untuk dijadikan organ konstitusi, seperti KPK dan Komnas HAM. Agar ketika terjadi sengketa kewenangan konstitusional, lembagalembaga tersebut mempunyai legal standing dalam berperkara di MK.

Ketiga, untuk memperkuat independensi kejaksaan, karena dengan memiliki dasar hukum yang kuat sebagai organ konstitusi sebaiknya kedudukan kejaksaan tidak ditempatkan lagi sebagai lembaga pemerintahan yang menjadi bagian eksekutif, melainkan menjadi lembaga negara mandiri yang direfleksikan dengan pengangkatan dan pemberhentian Jaksa Agung tidak hanya menjadi kewenangan Presiden semata sebagai Kepala Pemerintahan melainkan melibatkan peran DPR untuk memberikan persetujuan. Hal ini merupakan praktek lazim dalam negara demokratis untuk pengangkatan atau pengisian jabatan strategis tertentu membutuhkan keterlibatan parlemen sebagai wujud adanya checks and balances antara eksekutif dengan legislatif. ${ }^{34}$

34 Berdasarkan pendapat Peter L. Strauss, check and balances dalam upaya menciptakan relasi konstitusional untuk mencegah penyalahgunaan kekuasaan di antara cabang-cabang kekuasaan negara untuk membangun keseimbangan hubungan dalam praktik penyelenggaraaan negara. Jika dalam teori pemisahan kekuasaan dan pembagian kekuasaan lebih menggambarkan kejelasan posisi setiap cabang kekuasaan negara dalam menjalankan fungsi-fungsi konstitusionalnya, sedangkan check
Keempat, mempertegas kedudukan kejaksaan sebagai central of authority di bidang penuntutan. Di sini perlu ditata keberadaan kewenangan penuntutan yang ada di KPK berhadapan dengan kewenangan yang dimiliki oleh kejaksaan. Adanya dualisme ini tentu tidak baik dalam membangun hubungan kelembagaan yang efektif, sehingga potensi konflik akan terus membayangi ketika suatu fungsi atau urusan yang sama dikerjakan oleh dua lembaga atau lebih.

Kelima, urgensi penguatan kejaksaan dalam konstitusi seharusnya menempatkan lembaga ini memiliki kedudukan dan hu-bungan kelembagaan yang jelas dalam struktur ketatanegaraan sebagai sebuah fungsi atau kekuasaan negara yang independen bukan sebagai bagian dari eksekutif maupun yudikatif, meskipun memiliki keterkaitan terhadap keduanya. Oleh karena kekuasaan penuntutan dapat dianggap sebagai pelaksanaan kekuasaan sendiri dalam suatu fungsi dari lembaga-lembaga negara, sehingga tidak lagi mengklasifikasikan suatu lembaga negara hanya bersandarkan kepada pendekatan separation of powers dalam perspektif trias politica Montesquie semata. Atau bisa juga tetap mendasarkan penglasifikasian lembaga negara berdasarkan konsep trias politica dengan pengertian yang lebih luas, tidak hanya sebatas melihat lembaga negara terbagi antara eksekutif, legislatif dan

and balances lebih menekankan kepada upaya membangun mekanisme perimbangan untuk saling kontrol antar cabang kekuasaan negara. Bagaimanapun, mekanisme check and balances hanya dapat dilaksanakan sepanjang punya pijakan konstitusional guna mencegah kemungkinan terjadinya penyalahgunaan kekuasaan oleh cabangcabang kekuasaan negara. Lihat Saldi Isra, 2010, Pergeseran Fungsi Legislasi: Menguatnya Model Legislasi Parlementer Dalam Sistem Presidensial Indonesia, Jakarta, RajaGrafindo Persada, hlm. 78. 
yudikatif secara absolut. Menurut Saldi Isra, dalam perkembangan praktik ketatanegaraan modern tidak mungkin suatu cabang kekuasaan negara benar-benar terpisah dari cabang kekuasaan yang lain. Bahkan dalam pandangan John A. Garvey dan Aleinikoff melihat teori trias politica dalam praktik ketatanegaraan tidak mungkin memisahkan secara ketat cabang-cabang kekuasaan negara di mana pembagian kekuasaan tidak diistilahkan dengan separation atau distribution of powers, melainkan hanya berupa separation of functions. ${ }^{35}$

Ke depannya, dalam mengklasifikasikan atau melakukan pembagian kekuasaan dalam suatu negara termasuk di Indonesia, perlu dilihat adanya suatu pola hubungan yang terjadi antara lembaga-lembaga penyelenggara kekuasaan negara yang dibagi hanya dalam konteks separation of function di mana di dalamnya kejaksaan menjadi lembaga mandiri yang menjalankan fungsi penuntutan sebagai kekuasaan sendiri dalam struktur ketatanegaraan.

Secara keseluruhan, lembaga-lembaga kekuasaan negara tersebut dalam konteks Indonesia, dapat diklasifikasikan sebagai berikut: ${ }^{36}$

a) Kekuasaan konstitutif, yaitu kekuasaan untuk menetapkan dan mengubah Undang-undang Dasar Negara. Kekuasaan ini diwadahi dan dilaksanakan oleh lembaga negara yang disebut sebagai Majelis Permusyawaratan Rakyat (MPR).

$35 \quad$ Ibid, hlm. 77.

36 Anwar Sanusi (ed). (2010). Penataan Mekanisme Hubungan Antar Lembaga Negara, Jakarta, Pusat Kajian Kinerja Kelembagaan Lembaga Administrasi Negara, hlm. 21-23. b) Kekuasaan legislatif, yaitu kekuasaan untuk membentuk undang-undang. Kekuasaan ini dilaksanakan oleh Dewan Perwakilan Rakyat (DPR). Dalam penyusunan peraturan perundangan tertentu yang berkaitan dengan otonomi daerah, hubungan pusat dan daerah, pembentukan dan pemekaran serta penggabungan daerah, pengelolaan sumber daya alam dan sumber daya ekonomi lainnya, serta yang berkaitan dengan perimbangan keuangan pusat dan daerah, DPR melibatkan dan memerhatikan usulan dari Dewan Perwakilan Daerah (DPD).

c) Kekuasaan eksekutif, yaitu kekuasaan untuk menyelenggarakan kekuasaan pemerintahan negara. Kekuasaan ini dilaksanakan oleh Presiden.

d) Kekuasaan yudikatif, yaitu kekuasaan untuk menyelenggarakan kekuasaan kehakiman yang merupakan kekuasaan yang merdeka untuk menyelenggarakan peradilan guna menegakkan hukum dan keadilan. Kekuasaan ini dilaksanakan oleh Mahkamah Agung (MA) serta badan peradilan yang berada di bawahnya dan oleh Mahkamah Konstitusi (MK).

e) Kekuasaan auditif, yaitu, menyelenggarakan pemeriksaan atas pengelolaan dan tanggung jawab tentang keuangan negara. Kekuasaan ini dilaksanakan oleh Badan Pemeriksa Keuangan (BPK) yang bebas dan mandiri.

f) Kekuasaan moneter (otoritas moneter), yaitu menetapkan dan melaksanakan kebijakan moneter, mengatur dan menjaga kelancaran sistem pembayaran 
serta memelihara kestabilan nilai rupiah. Kekuasaan ini dilaksanakan oleh Bank Indonesia (BI) sebagai bank sentral Republik Indonesia.

g) Kekuasaan konsultatif, yaitu memberikan nasehat dan pertimbangan kepada pemerintah yang dahulu dilaksanakan oleh Dewan Pertimbangan Agung (DPA), namun dengan adanya amendemen UUD 1945, kekuasaan ini tidak berada pada level supreme lagi tetapi dilaksanakan oleh Dewan Pertimbangan Presiden (Wantimpres).

h) Kekuasaan attorney dan prosecutor (pengacara dan penuntut umum negara), yaitu melaksanakan kekuasaan negara dibidang penuntutan yang dilaksanakan oleh Kejaksaan Agung.

\section{PENUTUP}

Eksistensi kejaksaan dalam struktur ketatanegaraan Indonesia memiliki posisi yang dilematis. Di satu sisi, kejaksaan adalah lembaga penegak hukum yang menjalankan kekuasaan penuntutan, sedangkan di sisi yang lain, merupakan bagian dari lembaga pemerintahan. Kedudukan seperti ini menyebabkan munculnya perdebatan bahwa kejaksaan sebenarnya tidak tepat dikategorikan sebagai bagian lembaga eksekutif, karena tugas dan fungsinya terkait dengan kekuasaan kehakiman. Dalam UU No. 16 Tahun 2004, jelas menempatkan kejaksaan di bawah eksekutif, di mana Jaksa Agung diangkat dan diberhentikan oleh Presiden. Pun dengan penegasan bahwa kejaksaan adalah lembaga pemerintahan. Pengaturan ini tentu saja memiliki dampak terhadap independensi kejaksaan, sehingga memunculkan stigma bahwa kejaksaan hanyalah sebagai alat kekuasaan dari yang memerintah, apalagi dibuktikan dengan pengalaman selama rezim Orde Baru, di mana institusi kejaksaan dijadikan instrumen hukum untuk melibas lawan-lawan politik penguasa pada waktu itu.

Dalam kerangka membangun dan menata institusi kejaksaan dalam iklim yang demokratis saat ini, untuk ke depannya penguatan kejaksaan sebaiknya diatur langsung oleh konstitusi. Hal ini dimaksudkan untuk menjadikan kejaksaan sebagai bagian dari main state organ yang mempunyai legal standing sama seperti lembaga penegak hukum lainya, yaitu Kepolisian dan institusi peradilan (MA dan MK), serta untuk memerkuat dan memerjelas kedudukannya sebagai lembaga negara, memusatkan kewenangan penuntutan berada di Kejaksaan sebagai central of authority, membenahi hubungan kelembagaan antarsesama penegak hukum maupun lembaga terkait dan tentu saja memerkuat independensi kejaksaan sebagai lembaga mandiri yang menjalankan fungsi penuntutan dalam struktur ketatanegaraan Indonesia.

\section{BIBLIOGRAFI}

Anwar Sanusi (ed). (2010). Penataan Mekanisme Hubungan Antar Lembaga Negara. Jakarta: Pusat Kajian Kinerja Kelembagaan Lembaga Administrasi Negara.

Dio Ashar Wicaksana. (2013). "Kedudukan Kejaksaan RI dalam Sistem Hukum Tata Negara Indonesia". Jurnal Fiat Justitia, Vol. 1. No. 1, Maret 2013. Firmansyah Arifin dkk. (2005), Lembaga 
Negara dan Sengketa Kewenangan Antarlembaga Negara, Jakarta: Konsorsium Reformasi Hukum Nasional bekerjasama dengan Mahkamah Konstitusi.

Hans Kelsen. (2006). Teori Umum tentang Hukum dan Negara, Bandung: NusaMedia.

Ifdhal Kasim. (2011). "Komnas HAM dan Tantangannya Dewasa Ini". Jurnal Dignitas: HAM dan Realitas Transisional, Vol. VII, No. 1.

Ni'matul Huda. (2007). Lembaga Negara Dalam Masa Transisi Demokrasi, Yogyakarta: UII Press.

Saldi Isra. (2010). Pergeseran Fungsi Legislasi: Menguatnya Model Legislasi Parlementer dalam Sistem Presidensial Indonesia, Jakarta: PT. RajaGrafindo Persada.

\section{Sumber lainnya:}

Ahmad Andriadi. (2012). Kedudukan Kejaksaan dalam Sistem Ketatanegaraan Republik Indonesia (Telaah Kritis Terhadap Undang-Undang Nomor 16 Tahun 2004 tentang Kejaksaan Republik Indonesia). Skripsi. Makassar: Fakultas
Hukum Universitas Hasanudin.

Jimly Asshiddiqie. (2008). "Hubungan Antar Lembaga Negara Pasca Perubahan UUD 1945". Bahan ceramah pada Pendidikan dan Latihan Kepemimpinan (Diklatpim) Tingkat I Angkatan XVII Lembaga Administrasi Negara. Jakarta, 30 Oktober 2008.

Jimly Asshiddiqie. "Lembaga-lembaga Negara, Organ Konstitusional Menurut UUD 1945". Diunduh pada laman website: http://www.jimly.com/makalah/ namafile/50/ORGAN-ORGAN_KONSTITUSI.doc, diakses pada tanggal 2 Juli 2015.

Yusril Ihza Mahendra. "Kedudukan Kejaksaan dan Posisi Jaksa Agung Dalam Sistem Presidensial Di Bawah UUD 1945". Diunduh pada laman website: http://yusril.ihzamahendra.com/2010 /08/20/kedudukan-kejaksaan-dan-posisi-jaksa-agung-dalam-sistem-presidensial-di-bawah-uud-1945-oleh-profdr-yusril-ihza-mahendra-pendahuluan-hampir-seluruh-negara-moderndi-du/\#, diakses pada tanggal 30 Juni 2015. 